\title{
Union Politicization in Sri Lanka: Dimensions and Measurement
}

\author{
DHAMMIKA, K.A.S. ${ }^{1}$, AHMAD, F.B. ${ }^{2}$, SAM, T.L. ${ }^{3}$ \\ ${ }^{1}$ Department of Human Resource Management \\ University of Kelaniya \\ SRI LANKA \\ kasdhammika@yahoo.com \\ ${ }^{2}$ College of Business \\ Universiti Utara Malaysia \\ MALAYSIA \\ fais@uum.edu.my \\ ${ }^{3}$ College of Business \\ Universiti Utara Malaysia \\ MALAYSIA \\ 1sthi@uum.edu.my
}

\begin{abstract}
:-
Through trade unions are mostly viewed as employee organizations protecting employee's interests, they have political dimension too. Politicization of employee unions has added an extra complexity not only to their behavior, but also to their impact on organizations in industrial relations. Therefore, this political dimension of employee unions has to be taken into account in studies on unions.

Researchers have identified two dimensions of union politicization namely political instrumentality and political ideology. Measurement of union politicization should incorporate both the political instrumentality and political ideology dimensions of union politicization. However, past researches have used either the political instrumentality or political ideology in measuring union politicization depending on their research context. The aim of this study is to test the goodness of measure of the union politicization in Sri Lankan Context.
\end{abstract}


Data was collected from 136 public sector employee selected using stratified random sampling. Exploratory factor analysis and reliability testing were applied for testing the validity and reliability of the measurement. It was found that both political instrumentality and political belief dimensions are validly and reliably held in explaining the union politicization in Sri Lankan context. Further, results and implications are discussed so that it can be used for future research on union politicization.

Key Wards: Union Politicization, Political Instrumentality, Political Belief and Measurement

\section{Introduction}

Unions as employee organizations and employees' behavior as union members have been subjective to an extensive research over the past decades (Parks, Gallagher, and Fullagar, 1995). It is due to the fact that employee unions bring important implications not only to the industrial relation climate of organizations, but also to the overall functioning of them (Wickens, 2008). As a result, unions have been studied with different perspectives such as economic, psychological, political, and managerial perspectives (Gani, 1996; Opatha, 2001; Biyanwilla, 2003). But union research in recent years has placed an increased emphasis on organizational and behavioral approach to the study of employee unions (Parks, et al., 1995). Due to this renewal interest, some behavioral aspects related to unions, have been extensively explored. Among such variables, union commitment (Snape, Redman, \& Chan, 2000), union loyalty and union satisfaction, (Iverson \& Kuruvilla, 1995), union participation (Fuller \& Hester, 1998) and pro union attitudes and union instrumentality (Chan, TongQing, Redman and Snape, 2006) have been explored.

However, it is noted that some contextual aspects related to employee unions have not been much studied. Among such contextual dimention of unions not adequaltely examined, union ploiticization stands prominent given the fact that unions are highly political prone in some contexts. Unions in South Asian regoins, and in Sri Lanka particularly are identified as highly politicized (Biyanwilla, 2003;Jinadasa \& Opatha, 1999). Therefore, this political dimension of employee unions has to be taken in account in studies on union behaviour. However, it seems that the research on this important aspect is 
lagging behind specially in Sri lankan context. This may be attributed to non avilability of empiricaly tested measurement instrument for union politicizaion. Therefore, this study was purposed to test the dimentionality of union politicization in Sri lankan context

\section{Union Politics}

Though trade unions are conceptually viewed as employee organizations which represents the employees' interests, researcher claimed that they have a political dimension too. Hyman \& Gumbrell- McCormick, (2010) proposed that trade unions are not merely economic actors, they are necessarily actors in the political arena. This political dimension of employee unions has added an extra complexity not only to their behavior but also to their implications on organization , especially on industrail relation.

Unions engage in political activities for different reasons .One such reason was that employee unions are attached to political parties for increasing their influencing power, (Sturmthal, 1972). Other reasons for unions to be politicized are, as a strategy for mobilizing more employees for their union actions and to balance the power in context where economic power is eroding (Piazza, 2001). Consisting with these propositions, Neeta, (2008), provided evidence of successful engagement of political activities by unions in wining workers' right. She claimed that unions need to keep a balance of their political engagement in the era of eroding the economic role of unions in developing countries in the face of economic liberalization and globalization.

Some dimensions of union politicization have been identfied by researchers. Among indentified dimensions are political instrumentality ( Fiorito, 1987), political belief (Kelly, 1994; Charlwood, 2002), and employee voting intention (Leigh, 2006). However, political instrumentality and political belief are the two dimensions which have been attended mostly by researchers.

\section{Political Instrumentality}

Political instrumentality is the perception of union members that how far political activities of the union benefit them (Fiorito, 1987). However, it has been identified as a sub dimension of a broader construct known as union instrumentality. Union instrumentality is conceptualized as the beliefs that unions are able to improve the benefits for the members through collective 
bargaining and contact administration activities (Kochan, 1979). Early studies had identified two dimensions of union instrumentality as economic and non economic (Youngblood, William, \& Angelo, 1982). Later, it was conceptualized as union leadership and external power (Craft \& Suhail, 1983), of which external power dimension closely coincides with political instrumentality. Fiorito, (1987) distinguished them as workplace instrumentality and political instrumentality as parralel dimension of the broader construct of union instrumentality. This political instrumentality conceptually captures the political behaviour of union, measuring its politicality in oneway.

Though the political instrumentality is found to be explaining the political behaviour of unions as aggreagte unit, it is not explaining the political behaviour, or intention of union members at individual level. Later, reseachers identified another aspects of union politicization, explaining political belief of members literaly known as political belief or political ideology.

\section{Political Belief of Union Members}

Political belief or ideology is defined as the degree of perception of the members that union have to play a political role as well as the economic role in unionization process ( Kelly, 1994).Early record of identification of political view of employees as union dimension was recorded in the study of Adam, (1974). He claimed that the willingness of an employee to join with a union will be largely determined by his political view. Later, it was Kochan (1980) who distinguised between leftwing and right-wing ploitcal belief of union employees. Left-wing political belief is largely endosed with Marxist ideology where unions are considered as vehicle for class struggle (Neeta, 2008). Therefore, unions should gain a greater span of control over workplace in order to aviod employee exploitation ( Barling, et al.,1991). On the other hand, right-wing political view says that it it through the demoractic and peaceful encounter that employee should win their rights in workplace (re). In examining the political view of employees, Charlwood (2002) and Boxall, Haynes, and Macky (2006) found that employees with left-wing political view will be more likely to join employee unions than employees with right-wing politcal veiw. Adding to this is the fact that left-wing politically motivated employee percieve managerial performance less favourably 
while right-wing employee percieve it more favourablly (Boxall, et al.,2006).

Given the fact that reasons and implications for union politics may vary across countries and time (Hyman \& Gumbrell-McCormick, 2010), the relevance and the degree of important of union politicization dimension may differ from context to context. Therefore, an understanding of the context is needed before an empirical investigation is carried out.

\section{Union Politicization in Sri Lanka}

Employee unions in Sri Lanka specially unions in the public sector has been subjective to empirical investigation over the past years. It has been found that majority of public sector unions are politicized in term of affiation with the mainstream politics of the country( Nanayakkara, 1988: Biyanwila, 2003). Kearney (1971) pointed out that the political activities of trade unions are partisan activities, and unions are primarily concerned with the winning of the political power of the party with which they are alined. All major political parties have their own trade unions considered as labour wing of their parties. As a result, employee unions have been an avenue for political parties to express their rivaltry to each other ( Jayawardena, 1972).
On the other hand, mojority of the unions are based on left-wing political ideology( Uyangoda, 2000). However, politcal parties with right-wing ideology have their own trade unions in most of organizations. Therefore, it can be deduced that trade unions in Sri Lanka are affiliated with both left-wing and right-wing politcial ideology.

Political view of union members largely determine the nature of the activities a union engage in . For instance, Murrillo and Ronconi (2004) concluded that it was the political motivation of unions that make them more prone to strike behavior than other factors.

Based on the above empirical accounts, it is obvious that politicization is one of the major aspects of employee unions in Sri Lanka. Therefore, any examination of the union in general and union behavior in particular should include this union politicization dimension in Sri Lankan context. Measurement of union politicization is the major aspect of such empirical examination. The present study is aimed at testing the goodness of a measure of union politicization based on two identified dimensions of politicization, namely political instrumentality and political belief. 


\section{Measurement of Union}

\section{Politicization}

Measurement of union politicization has to assess the two identified dimensions of politicization i.e. political instrumentality and political ideology. The measurement to be tested under this study was adopted from the 10 items union instrumentality measure of Fiorito (1987) and the 5 item measure of political belief of British Attitude Survey, taken from Charlwood (2002).

It was noted some overlap can be seen among researchers between items measuring political instrumentality and work place instrumentality. For example, some items of Kotchan's (1979) big power dimension and Chacko and Green's (1982) power dimension coincide with political instrumentality of Fiorito. But some items are not consistent. It may be due to the fact that both political instrumentality and work place instrumentality comes under a broader construct of union instrumentality and some of the items are difficult to distinguish whether measuring political instrumentality or workplace instrumentality ( For instance, Are unions more powerful than employer?). Therefore, it was decided to include items of both political instrumentality and workplace instrumentality in the measurement to be tested and extracted only the items that loaded high with political dimension at the initial testing. The items of the measurement were scaled with Likert's five point scale from 1 anchored with strongly disagree to 5 anchored with strongly agree.

\section{Method}

\subsection{Sample}

The sample of this study included 200 employees from the public sector organizations in Sri Lanka. Anyway, only 145 respondents responded to the distributed questionare of which 9 were found to be incomplete and were excluded, redusing the number of responses to 136 which is a $68 \%$ response rate. The was selected with stratified random sampling in order to ensure that appropriate number of employees are selected from sample organizations.

The profile of the sample is such that $64.7 \%$ were male and 35.3 were female. Further, $61 \%$ of respondents are between 21-40 year age category while $33.8 \%$ are more than 40 years old. Sample respondents come from diverse educational background, $46.7 \%$ representing G.C.E.(A/L), $26.2 \%$ are graduate and $10.4 \%$ are with 
postgraduate qualifications. Majority of respondents (58.1\%) has work experience 5-10 years and $16.9 \%$ has more than 10 years experience.

\subsection{Data Analysis}

Exploratory factor analysis (EFA) and reliability analysis were used to test the validity and the reliability of the measurement of the three employee outcomes. It was intended to use exploratory factor analysis on the ground that no previous test of these measures have been done in Sri Lankan context. Byrne,( 2010) claimed that EFA is designed for situation where links between the observed and latent variables are unkonwn or uncertain. It will help researcher to determine how and to what extent observed variable are linked with the underline factor. Other researchers too have used EFA for the testing of goodness of measures of various variables (Wlliams \& Anderson, 1991).

Cronbach Alpha is widely used relaibility coefficeint for assessing the reliability of a measurement instrument. It measures the degree to which the test score indicates the status of an individual item on the factor defined by the test, as well as the degree to which the test score demostrate individual differences in these traits (Cronbach \& Meehl, 1955). Cronbach Alpha specifies that if the sum of the individual item variance is closer to the variance of the entire scale, alpha value come closer to zero, stating that they are not measuring the same construct. On the other hand, if the variance of the entire scale is much larger than the sum of the variance of individual items, alpha get a value closer to one.

\section{The Result}

An initial factor analysis was carried out with the 15 items with the aim of identifying the factor structure of the measurement instrument of which the result is shown in the following table 
Table 1 Rotated Component Matrix

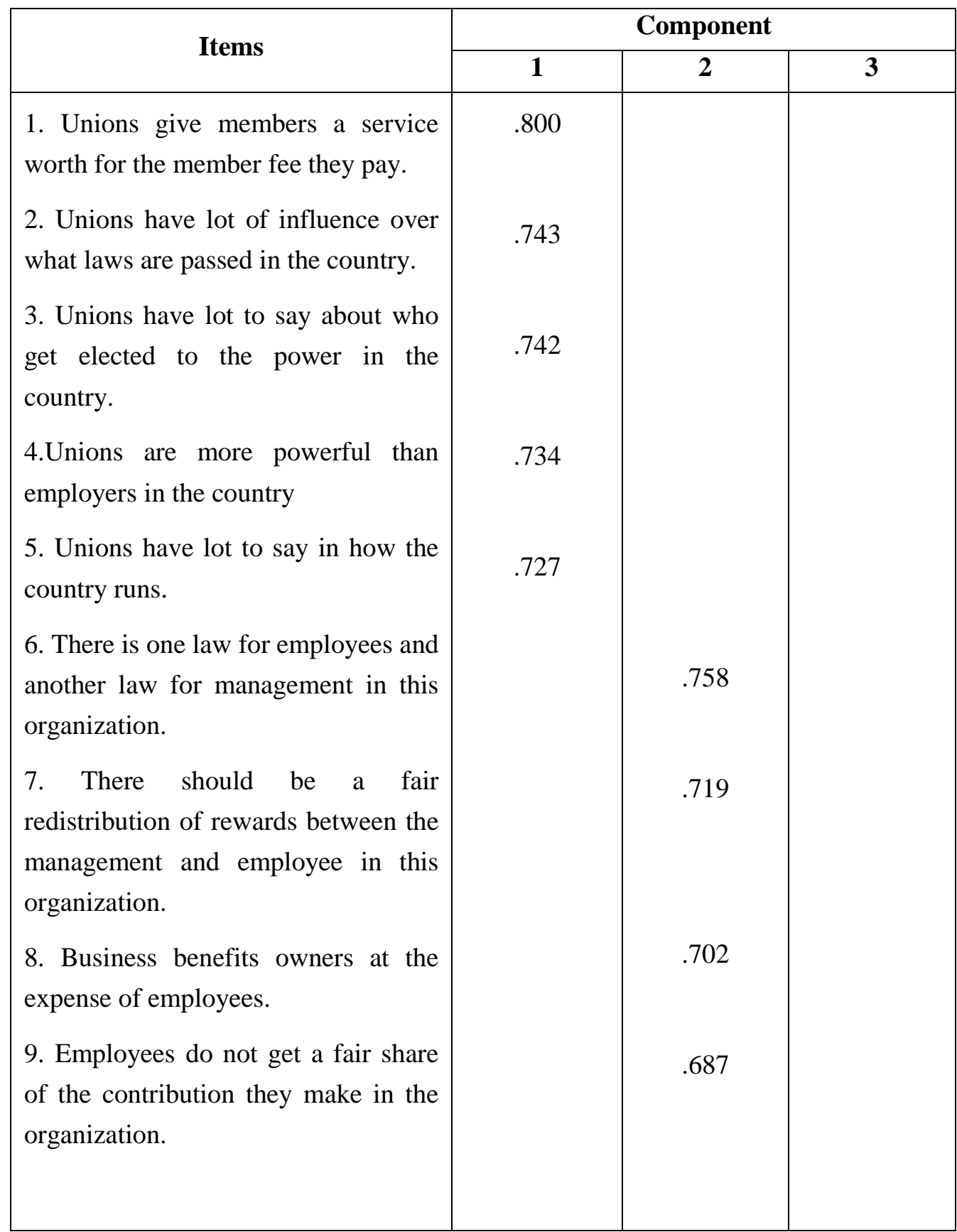




\begin{tabular}{|c|c|c|}
\hline 10. Management always tries to get & \multirow[t]{6}{*}{.647} & \\
\hline $\begin{array}{l}\text { 11. Union requires members to go } \\
\text { along with decision they don't like. }\end{array}$ & & .774 \\
\hline $\begin{array}{l}\text { 12. Unions improve the job security } \\
\text { of the workers }\end{array}$ & & .672 \\
\hline $\begin{array}{l}\text { 13. Unions improve the wages and } \\
\text { working conditions of workers. }\end{array}$ & & .655 \\
\hline $\begin{array}{l}\text { 14. Unions have leaders who do what } \\
\text { is best for them rather than what is } \\
\text { best for members. }\end{array}$ & & .639 \\
\hline $\begin{array}{l}\text { 15. Union protect employees from } \\
\text { unfair action be employer. }\end{array}$ & & .600 \\
\hline $\begin{array}{l}\text { Extration Method: Principle } \\
\text { Componant Analysis }\end{array}$ & \multirow{2}{*}{\multicolumn{2}{|c|}{$\begin{array}{l}\text { instrumentality (Factor I) and the } \\
\text { remaining items of workplace } \\
\text { instrumentality were loaded with that } \\
\text { factor (Factor3). The items of political } \\
\text { belief dimension were loaded with each } \\
\text { other as initially expected (Factor 2). }\end{array}$}} \\
\hline $\begin{array}{l}\text { Rotation Method: Varimax with } \\
\text { Kaiser Normalization }\end{array}$ & & \\
\hline
\end{tabular}

a.Rotation converged in 5 iteration

As shown in the table I, the initial factor analysis with all items of workplace instrumentality, political instrumentality and political belief extracted three factors measurement model. However, one item of the workplace Since the very objective of this study is to test the goodness of the union politicization measurement adapted, factor analysis was done again by excluding the workplace instrumentality items and the result is given in the table II instrumentality (unions give members a service worth for the member fee they pay) was loaded with the political 


\section{Table 2}

\section{Rotated Component Matrix}

\begin{tabular}{|c|c|c|}
\hline \multirow{2}{*}{ Items } & \multicolumn{2}{|c|}{ Factor } \\
\hline & 1 & 2 \\
\hline $\begin{array}{l}\text { 1. Unions give members a service worth for the } \\
\text { member fee they pay. }\end{array}$ & .807 & \\
\hline $\begin{array}{l}\text { 2. Unions have lot to say about who get elected to } \\
\text { the power in the country. }\end{array}$ & .792 & \\
\hline $\begin{array}{l}\text { 3. Unions are more powerful than employers in } \\
\text { the country }\end{array}$ & .756 & \\
\hline 4. Unions have lot to say in how the country runs. & .734 & \\
\hline $\begin{array}{l}\text { 5. Unions have lot of influence over what laws are } \\
\text { passed in the country. }\end{array}$ & .725 & \\
\hline $\begin{array}{l}\text { 6. There is one law for employees and another law } \\
\text { for management in this organization. }\end{array}$ & & 736 \\
\hline $\begin{array}{l}\text { 7. There should be a fair redistribution of rewards } \\
\text { between the management and employee in this } \\
\text { organization. }\end{array}$ & & .737 \\
\hline $\begin{array}{l}\text { 8. Business benefits owners at the expense of } \\
\text { employees. }\end{array}$ & & .706 \\
\hline $\begin{array}{l}\text { 9. Employees do not get a fair share of the } \\
\text { contribution they make in the organization. }\end{array}$ & & .685 \\
\hline $\begin{array}{l}\text { 10. Management always tries to get the better of } \\
\text { the employee. }\end{array}$ & & .652 \\
\hline
\end{tabular}

\section{Extraction Method: Principle} componant Analysis

Rotation method: Varimax with Kaiser Normalization a.Rotation converged in 5 iteration
The 10 items of the original instrument after deleted workplace instrumentality items were loaded with two factors as shown in the above able. The first five items were loaded with the union instrumentality (Factor 1) and the last 
five factor measures the political belief dimension ( Factor 2). Kaiser-MeyerOlkin measurer (KMO) was .729 and the Bartlett's test of sphericity was significant with $\chi 2=557.11, \mathrm{p}<.000$.

The sharp extraction of two factor model of measurment for union politicization is further evident for the scree plot which is shown bellow. It shows a break of the steep slope of the plot after two factors.

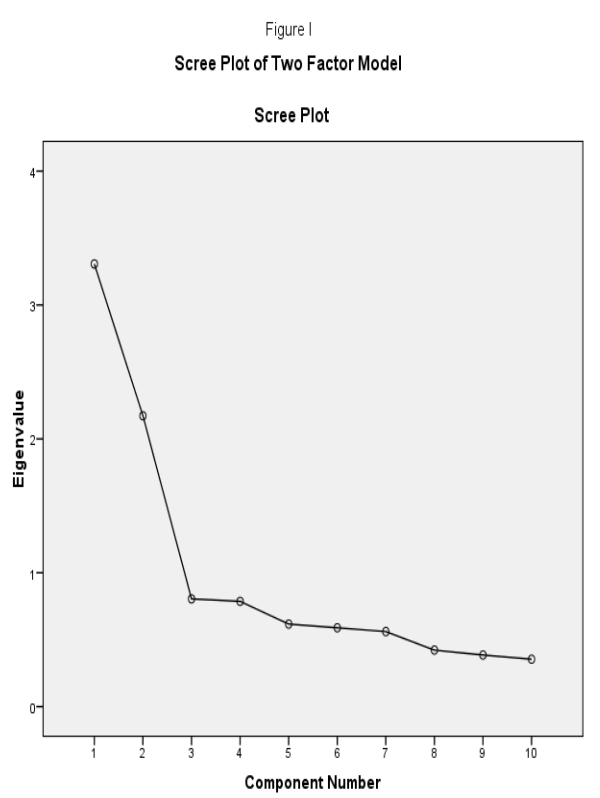

The total variance explain by the two factor model is such that $33 \%$ of variance in union politicization is explained by the first factor identified as political instrumentality and $21 \%$ by the second factor which is political belief dimension. The two factor model is able to explain $54 \%$ of total variance which is an acceptable level.
The Cronbach Alpha reliability coefficient for political instrumentality dimension and political view dimension recorded a value of .82 and .75 representing a good level of reliability. The correlation between the two dimensions was .48 which indicates an acceptable level of discriminant validity of the two factor model of measurement.

\section{Discussion and Conclusion}

The objective of the study reported here was to test the goodness (Validity and Reliability) of measure of union politicization adapted from political instrumentality of Fiorito (1987) and measure of political belief of Charlwood (2002) in Sri Lankan Context. The measure tested incorporated both political instrumentality and political belief dimensions given the fact that unions in Sri Lanka, particularly unions in the public sector are highly politicized (Biyanwilla, 2003) and motivated by political ideology ((Uyangoda, 2000).

The initial Exploratory Factor analysis with principle component analysis and varimax rotation, extracted a three factor model of measurement with work place instrumentality, political instrumentality and political belief dimension. A noteworthy observation in 
the initial analysis is that, one of the items for workplace instrumentality (unions give members a service worth for the member fee they pay) was loaded high with political instrumentality dimension. This may be due to the fact that respondents might have perceived that most of the benefits they received from unions are due to political activities of the union they represent.

However, the second analysis, by excluding items of workplace instrumentality, it was extracted two factor model of measurement loading each items with respective dimension. The first factor identified as political instrumentality recorded the highest value for percentage of variance explained (33.7\%). Political belief dimension explain only $21.7 \%$ of variance in political behavior. Therefore, it can be inferred that political instrumentality is the most significant factor for explaining political behavior of unions in Sri Lanka. This is in line with the findings of other studies that union members perceived that workplace benefits can be improved by unions engaging in political activities. It is because union can influence the policy decisions of management largely with political behavior ( (Jinadasa \& Opatha, 1999).
The reliability level of each dimension recorded high (Chronbach Alpha=.82, .75) indicating a high reliable level. Further, since the correlation between the two dimensions was moderate level, the descriminant validity of the measure can be assumed to be high. Two dimensions identified; political instrumentality and political belief seem to be highly relevant in explaining union politicization in Sri Lanka. Therefore, the measurement tested by this study can be used validly and reliably for measuring the union politicization in Sri Lankan context.

\section{References}

Adam, R. J. (1974). Solidarity: Self interest and unionization differencial between Europe and North America. Industrial Relation , 29 (3), 497-512.

Baird, C. W. (1981). Unionism and Public Sector. Managerial and Decision Economics , 2 (2), 82-90.

Barling, J., Kelloaway, E. K., \& Bremerman, E. (1991). Pre-employment predictors of Union Attitudes: The role of family unionization and work belief. Journal of Applied Psychology , 76 (5), 725-731. 
Biyanwilla. (2003). Trade Union in Sri Lanka under Globalization: Reinventing Wokers Solidarity. The university of Western Australia: PhD, thesis, .

Boxall, P., Haynes, P., \& Macky, K. (2006). Prediction of Union Belonging in New Zealand.

Byrne, B. M. (2010). Structural Equation Modeling with AMOS: Basic concepts, applications, and programming. (2, Ed.) New York: Taylor \& Francis.

Chacko, I. T., \& Greer, C. R. (1982). Perception of union power, service and confidence in labour leader: A study of member and non member differenses. Journal of Labour Research , 3, 211221.

Chan, A. W., Tong-Qing, F., Redman, T., \& Snape, E. (2006). Union Commitment and Participation in the Chinese context. Industrial Relation , 45 (3), 485-489.

Charlwood, A. (2002). Why do nonunion employees want to unionise: Evidence from Britin. British Journal of Industrial Relation, , 40, 463-491.

Craft, A. J., \& Suhail, A. (1983). The union image: Concepts, programme and analysis. Journal of Labour Research , 4, 297-314.
Cronbach, L. J., \& Meehl, P. E. (1955). Construct Validity in psychological test. Psychological Bulletin , 52, 281-302.

Fiorito, J. (1987). Political Instrumentality Perceptions and Desire for Union Representation. Journal of Labour Studies , 8 (3), 271-290.

Fuller, J. B., \& Hester, K. (1998). The effect of labour relations climate on the union participation process. Journal of Labour Research , 19 (1), 173-187.

Gani, A. (1996). who joins the unions and Why? Evidencre from India. International Journal of Manpower , 17 (6), 54-65.

Hyman, R., \& Gumbrell-McCormick, R. (2010). Trade unions, politcis and parties: is a new confuguration possible.

Transfer , 16 (3), 315-331.

Iverson, R. D., \& Kuruvilla, S. (1995). Antecedent of Union Loyalty: the influence of individual dispositions and organizational context. Journal of Organizational Behavior, 16, 557-582.

Jayawardena, K. (1972). The Rise of the Labour Movement in Ceylon. Durman, North Carolina: Duke univerity Press.

Jinadasa, P. V., \& Opatha, H. P. (1999). An Emperical Study of Membership Participation in Trade Union Activities: 
Evidence from selected service Postgraduate Institute of Management, organizations in Sri Lanka. Sri Lanka.

Sabaragamuwa University Journal , 2 (1), 17-34.

Neeta, M. (2008). Strategic Unionism: The political role of The congress of Kearney, R. N. (1971). Trade Unions South African Trade unions(COSATU) and Politics in Ceylon. New Delhi: in South Africa and what it means for Thomas Press India (PVT) limited.

Kelly, J. (1994). Rethinking Industrila Relation,. Retrieved December 10, 2010, from http://books.google.com/books?hl=en\&l r

Kochan, A. T. (1979). How american workers view labour unions. Monthly Labour Review , 102, 23-31.

BIBLIOGRAPHY $\backslash 1033$ Leigh, A. (2006). How do unionist vote?

Estimating the causal impact of union membership on voting behaviour from 1966 to 2004. Discussion Paper No.516

. Centre for Economic Policy Research, The National University of Australia.

Murillo, M. V., \& Ronconi, L. (2004).

Teaches' Strikes in Agentina: Partisan allignment and publi-sector labour relation. Studies in Comparative International Development , 39 (1), 77 98.

Nanayakkara, G. (1998). Cultue and Management in Sri Lankla. Dehiwala: Back workers, PhD Dissetation. USA: Massachusetts Institute of Technology .

Opatha, H. H. (2001). Factors Contributing to Labour Management Relationship in Sri Lanka: An Empirical Analysis in Manufacturing Sector, PhD Thesis. Sintok: University Utara Malaysia.

Parks, J. M., Gallangher, D. G., \& Fullagar, C. J. (1995). Operationalizing the outcomes of union commitment: the dimentionality of participation. Journal of Organizational behaviour , 16, 533555.

Piazza, J. (2001). De-Linking Labour: Labour union and social democratic parties under globalization. Party Politics , 7 (4), 413-435.

Snape, E., Redman, T., \& Chan, A. W. (2000). Commitment to the union: a survey of research and the implications for industrial relation and trade unions. International Journal of Management Review, 2 (3), 205-230. 
Sturmthal, A. Comparative Labour behaviour. Journal of Management , 17 Movement: Ideological roots and (3), 601-617. institutional development. In R. Hyman, \& R. Gumbrell-McCormick.

Youngblood, A. S., William, M. H., \& Angelo, D. S. (1982). Attitudes, Uyangoda, J. (2000). Post independent perception and intension to vote in social movement. In W. D. Lakshaman, union cerification Election: An \& C. A. Tisdaell, Sri Lanka's emperical investigation. 24th Annual Develoipment since Independence: Meeting of the industrial Relation Socio-economic Perspectives and Research Association, (pp. 244-253). Analysis. NY: Nova Science Publishers.

Wickens, C. M. (2008). The organizational impact of university labour unions. Higher Education , 56, 545-564.

Wlliams, L. J., \& Anderson, S. E. (1991). Job satisfaction and organizational commitment as predictor of organizational citizenship and in-role 